\title{
Diabetes mellitus in the elderly: insulin resistance and/or impaired insulin secretion?
}

\author{
AJ Scheen \\ Division of Diabetes, Nutrition and Metabolic Disorders, Department of Medicine, CHU Sart Tilman, University of Liège, Liège, Belgium
}

\begin{abstract}
SUMMARY
Elderly people are more glucose intolerant and insulin resistant than young individuals, and many of them will develop type 2 diabetes. It remains, however, controversial whether this decrease in function is due to an inevitable consequence of "biological aging" or due to environmental or lifestyle variables. Indeed, increased adiposity/altered fat distribution, decreased fat free mass/abnormal muscle composition, poor dietary habits and physical inactivity all contribute to reduce insulin sensitivity. Insulin resistance in elderly people appears to predominate in skeletal muscle, whereas hepatic glucose output seems to be almost unaffected. Several abnormalities in islet $\beta$-cell and insulin secretion were also pointed out in elderly people such as increased amyloid deposition and decreased amylin secretion, impaired insulin secretion pulsatility, decreased insulin sensitivity of pancreatic $\beta$-cells to insulinotropic gut hormones and diminished insulin response to non-glucose stimuli such as arginine. Controversial results were reported concerning the effects of aging on absolute insulin secretion in response to oral or intravenous glucose. However, insulin secretion appears to decrease with age, with significantly diminished $\beta$-cell sensitivity and acute insulin response to glucose, provided it is analyzed relative to concomitant decreased insulin sensitivity. Thus, there is an interplay between decreased insulin secretion and increased insulin resistance that largely explains the abnormal glucose metabolism seen in elderly. Weight loss, especially reduction of abdominal adiposity, and increased physical activity may contribute to improve insulin sensitivity and glucose tolerance, and prevent the development of type 2 diabetes in elderly people.
\end{abstract}

Key-words: Insulin secretion $\mathbf{~}$ Insulin resistance $\mathbf{a}$ Elderly $\mathbf{a}$ Glucose tolerance $\mathbf{a}$ Diabetes mellitus.

\section{RESUME}

Le diabète du sujet âgé : insulinorésistance et/ou altération de la sécrétion d'insuline ?

Les sujets âgés sont plus intolérants au glucose et davantage insulino-résistants que les sujets jeunes, et nombre d'entre eux vont développer un diabète de type 2. Le fait de savoir si cette diminution fonctionnelle est la conséquence inéluctable du vieillissement biologique ou est secondaire à des modifications liées à l'environnement et au style de vie fait toujours l'objet de controverses. En effet, une augmentation de l'adiposité et/ou une anomalie de la distribution de la masse grasse, une diminution de la masse musculaire et/ou une altération de la composition du muscle squelettique, enfin, de mauvaises habitudes alimentaires et un manque d'activité physique sont tous des facteurs qui contribuent à réduire la sensibilité à l'insuline. L'insulinorésistance des sujets âgés semble prédominer dans le muscle squelettique, alors que le débit glucose hépatique ne paraît guère affecté. Plusieurs anomalies ont été également mises en évidence en ce qui concerne la cellule $\beta$ des îlots de Langerhans du pancréas et la sécrétion d'insuline chez les sujets âgés, avec une augmentation des dépôts d'amyloïde et une sécrétion réduite d'amyline, une altération de la sécrétion pulsatile d'insuline, une diminution de la sensibilité de la cellule $\beta$ vis-à-vis des hormones digestives de type incrétine et une réduction de la réponse à des stimuli non glucosés comme l'arginine. Des résultats contradictoires ont été rapportés à propos des effets du vieillissement sur la réponse insulino-sécrétoire absolue en réponse à l'administration de glucose par voie orale ou intraveineuse. Cependant, il apparaît que l'insulinosécrétion diminue avec l'âge, avec en particulier une diminution de la sensibilité de la cellule $\beta$ et de la réponse insulinique précoce au glucose, à condition d'analyser la réponse insulinosécrétoire en tenant compte de la diminution concomitante de la sensibilité à l'insuline. Il existe, en effet, une étroite interrelation entre la diminution de l'insulinosécrétion et l'augmentation de l'insulinorésistance et cet effet synergique explique l'essentiel des anomalies du métabolisme du glucose observées chez le sujet vieillissant. La perte de poids, en particulier la réduction de l'adiposité abdominale, et l'augmentation de l'activité physique peuvent contribuer à améliorer la sensibilité à l'insuline et la tolérance au glucose et donc à prévenir la survenue d'un diabète de type 2 chez les sujets âgés.

Mots-clés : Diabète sucré @ Insulinorésistance — Insulinosécrétion — Sujet âgé @ Tolérance au glucose. 
Aging is associated with a decline of many, if not all, human physiological functions. The reduction in wholebody carbohydrate metabolism in the elderly is one of the hallmarks of the aging process, and substantial evidence shows that increasing age is associated with decreased glucose tolerance and type 2 diabetes [1-5]. The decline in glucose tolerance is reflected in NHANES III (Third National Health and Nutrition Examination) survey on the prevalence of diabetes and impaired fasting glucose and impaired glucose tolerance in US adults [6]. Comparison of the percentage of physician-diagnosed diabetes in middle-aged adults (40-49 years) and elderly adults ( $\geq 75$ years) reveals an increase from $3.9 \%$ to $13.2 \%$. In addition, the percentage of adults with undiagnosed diabetes (fasting plasma glucose $\geq 126 \mathrm{mg} / \mathrm{dl}$ ) increased from $2.5 \%$ to $5.7 \%$ and with impaired fasting glucose $(110-125 \mathrm{mg} / \mathrm{dl})$ increased from $7.1 \%$ to $14.1 \%$. Thus, approximately one third of the elderly adults in the USA have abnormal glucose metabolism.

A significant decrease in glucose tolerance with increasing age can be demonstrated from all epidemiological studies. The glucose intolerance of aging is manifested primarily by an increase in the postprandial blood glucose response while fasting blood glucose levels are generally only modestly elevated. After 50 years, fasting blood glucose levels rise by $0.06 \mathrm{mmol} / 1$ per decade and 2-hour levels in an oral glucose tolerance test (OGTT) by $0.5 \mathrm{mmol} / 1$ [1]. Glucose intolerance is probably attributable to a multiplicity of causes such as poor diet, physical inactivity, decreased lean body mass, increased visceral adiposity, decreased relative insulin secretion and peripheral insulin resistance [7,8]. A detailed review of the specific effects of aging on glucose homeostasis has recently been published in a number of relevant articles [9-13]. Molecular abnormalities that occur in elderly patients with diabetes have not been fully elucidated. The glucokinase gene is the glucose sensor of the $\beta$-cell. Theoretically, alterations in this gene could explain defects in insulin secretion, but it is not clear whether the function of this gene is impaired in older people with diabetes. Insulin-receptor tyrosine kinase activity has been reported to be altered in elderly people with diabetes and insulin resistance, but it is uncertain whether this is the cause or the result of the elevated glucose levels in these patients [4]. Finally, other metabolic defects have recently been defined in elderly patients with diabetes. It has been shown that non-insulin mediated glucose uptake was significantly impaired in elderly patients with type 2 diabetes [14], Such abnormality may be important as in normal subjects, approximately $50 \%$ of glucose uptake after a meal occurs as a result of noninsulin-mediated glucose uptake. The present review focuses on the clinical evidence of a change with age in insulin sensitivity and insulin secretion, possibly independent of changes in other known factors. It also emphasizes the interplay between defects in insulin secretion and insulin action leading to a high prevalence of abnormal glucose tolerance and type 2 diabetes in the elderly population (Fig. 1).

\section{Insulin resistance}

Insulin resistance is defined as a reduction compared to the normal range in the rate of glucose disposal elicited by a given insulin concentration $[15,16]$. In practice, insulin resistance is not measured directly, but several methods exist for the measurement of insulin sensitivity [17]. Insulin resistance in the older population has been documented using a variety of techniques, among which the euglycaemic hyperinsulinaemic clamp, the hyperglycaemic clamp and the minimal model technique. There is a large body of literature to suggest that aging causes a peripheral resistance to the action of insulin $[9,12,18,19]$. Differences between young and old subjects remained present even when glucose disposal was expressed per kilogram of lean body mass, ruling out decreased lean body mass as a cause of the impaired glucose tolerance associated with aging. However, a large recent study analyzing euglycaemic insulin clamp data collected at 20 centers throughout Europe from 1,146 healthy men and women with normal glucose tolerance, ranging in age from 18 to 85 years, concluded that age per se is not or only a weak cause of insulin resistance [20]. Another recent in vivo (OGTT) and in vitro (adipose tissue glucose uptake) study also suggested that aging per se does not influence glucose homeostasis, but this study compared middle-aged rather than elderly individuals with young subjects [21]. Thus, the respective roles of age per se and various confounding factors in the decrease of insulin action usually seen in older patients remain to be evaluated [12] (Table I).

The mechanisms underlying the development of insulin resistance are multifactorial [8]. Aging is associated with an increase in body weight and fat mass, together with a loss of fat-free mass. It is also accompanied by alterations in the insulin signalling pathway $[11,12]$. Abdominal fat and visceral adiposity are correlated with hyperinsulinaemia and insulin resistance. Dietary constituents have also been shown to modulate insulin sensitivity, especially in the elderly, with increased fat content and reduced amount of carbohydrates leading to insulin resistance [22]. Modifications of the changes in body composition with aging by diet [22] and exercise training [23] could delay the onset of insulin resistance. Lifestyle modifications including body weight loss and physical activity provide health benefits and functional gains, and should be promoted to increase insulin sensitivity and prevent glucose intolerance and type 2 diabetes mellitus in older adults [12]. 
Figure 1: Illustration of the main abnormalities influencing insulin secretion and insulin sensitivity in elderly people.

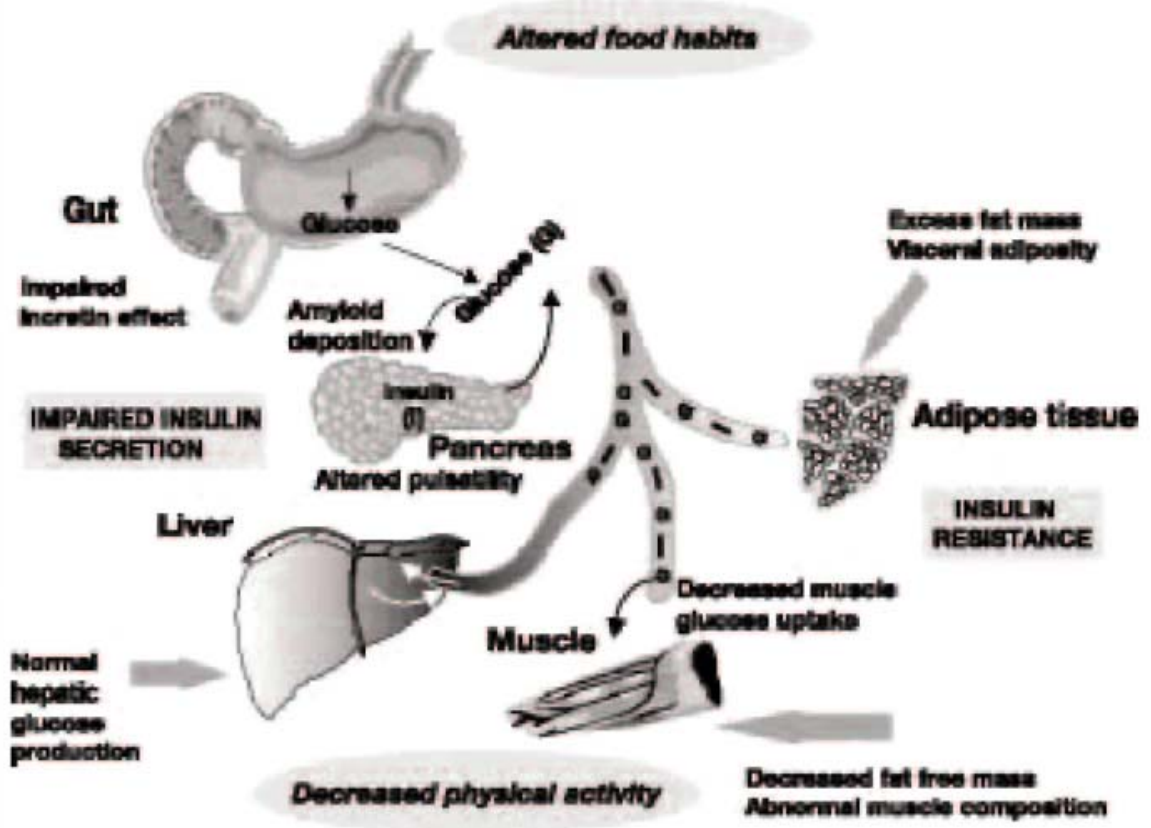

Table I: Contributors, markers and possible mechanisms of defects in insulin action in elderly people.

\section{Contributors}

Increased total fat mass

Increased abdominal (visceral) adiposity

Reduced fat free mass (skeletal muscle)

Abnormal muscle composition

Poor dietary habits (increased fat, decreased carbohydrate)

Physical inactivity

Comorbidities

Concomitant drugs

\section{Markers}

Increased fasting plasma insulin

Increased post-glucose load late plasma insulin levels (OGTT

Decreased insulin-mediated glucose disposal (clamp)

Decreased SI index (IVGTT + MinMod)

Preserved hepatic insulin sensitivity

\section{Potential mechanisms}

Decreased GLUT4 transporters

Decreased IGF-1

Decreased insulin-mediated increase in blood flow

Decreased cellular insulin signalling

\section{Effect of age on hepatic glucose production}

Hepatic glucose production (HGP) plays a major role in glucose homeostasis, both in the fasting and in the postprandial states [24]. The role of the liver in the maintenance of plasma glucose level has been best evaluated with the hyper-insulinaemic euglycaemic clamp. Dose-response relationships between plasma insulin levels and HGP clearly demonstrate that, in non-diabetic subjects, the liver is exquisitely sensitive to insulin and HGP is completely suppressed at plasma insulin levels well below the commonly used insulin dose [17]. There is no 
difference in either the basal HGP or the dose-response curve of its suppression by insulin between young and old individuals [25]. However, with low dose of insulin infusions, HGP is more rapidly suppressed in the elderly, perhaps due to a delayed suppression of endogenous insulin release in the older individuals. The European Group for the Study of Insulin Resistance (EGIR) reported a tendency $(\mathrm{P}=0.10)$ for HGP to decline with increasing age, but any significance was completely lost when adjusted for lean body mass [26]. Furthermore, hepatic glucose output has been shown not to be increased in elderly patients with type 2 diabetes [27]. Thus, hepatic insulin resistance does not seem to play a significant role in decreased glucose tolerance of elderly people.

\section{Effect of age on muscle glucose utilization}

Skeletal muscle is the primary sink for insulin-mediated glucose uptake as adipose tissue is relatively inert and accounts for only $2-3 \%$ of glucose uptake. The majority of reports examining the role of age on glucose uptake, utilizing a variety of techniques [17], have demonstrated decreased muscular insulin sensitivity during hyperinsulinaemia $[9,11,12,18]$. In the report by EGIR [20], age was associated with a significant decrease in insulin-mediated glucose disposal measured during a euglycaemic hyperinsulinaemic clamp in univariate analysis, but this effect was no longer significant when adjusted for BMI. Thus, this large multicentre study demonstrated that glucose uptake is not altered as a function of age per se. Despite the strength of the EGIR study, the issue of age-related insulin resistance is still controversial, because it has been argued that complete dose-response curves are necessary to resolve the issue. In a dose-response study [28], an age-associated decrease in glucose utilization was demonstrated with preservation of maximal glucose uptake (i.e. shift of the dose-response curve to the right), and this relationship remained when the glucose utilization was plotted per kilogram of lean body mass. This study is in agreement with other studies where several insulin doses were employed $[29,30]$. In addition, studies using various techniques, including the hyperglycaemic clamp, the forearm glucose uptake technique and the intravenous glucose tolerance test assessed with the minimal model, have revealed resistance to insulin-induced glucose disposal in aged individuals $[9,11,12,18]$, However, it is obvious that, in addition to age, various factors may influence insulin sensitivity including fat mass, fat distribution, physical fitness and dietary composition, besides genetic factors. When all these factors are taken into account, it is not clear that age per se still has an independent effect on peripheral glucose uptake.

Aging is associated with an increase in body weight and body fat and a loss of fat-free mass. The body fat accumulation is particularly evident in the abdominal region. The amount of intra-abdominal fat is directly correlated with glucose intolerance and severity of insulin resistance, even after controlling for obesity [31]. In addition, insulin resistance is more closely associated with abdominal adiposity than with age [32, 33]. Collectively, these data support a relationship between abdominal obesity and the development of insulin resistance in the elderly. A large body of evidence shows that even a modest to moderate body weight loss (5$10 \%$ of initial body weight) increases insulin sensitivity and improves glucose tolerance in obese individuals as well as in those with impaired glucose tolerance or type 2 diabetes [12, 34].

Besides central obesity, there has been recent interest in perturbations in skeletal muscle and their role in insulin sensitivity and glucose homeostasis [35]. Reduced attenuation of muscle in computerized tomography is largely the result of increased fat content in and around muscle fibres. Insulin-stimulated glucose uptake is negatively correlated with low density lean tissue [35], and lean tissue with a density below the normal range increases with age [36]. Thus, reduced attenuation of muscle may be another body composition characteristic important in the development of insulin resistance, but to date no study has supported this notion in the elderly [12].

In addition to insulin-stimulated glucose uptake in skeletal muscle, a second mechanism whereby glucose uptake increases in muscle is by muscle contraction. This process may involved adenosine 5 '-monophosphate-activated protein kinase (AMPK). Increased recruitment of the AMPK signalling system by exercise (or drugs) may correct insulin resistance in patients with impaired glucose tolerance or type 2 diabetes mellitus resulting from defects in the insulin signalling cascade [37]. Lack of physical exercise frequently observed in elderly people may thus contribute to insulin resistance, and this may be improved with an aerobic exercise training programme $[12,23]$. Such exercise-related improvement occurs with [38] or without [39] changes in body weight or fat mass, and improved insulin sensitivity may be accompanied by a reduction of $\beta$-cell secretory capacity without a change in glucose tolerance [23].

Various mechanisms have been proposed to explain insulin resistance in elderly people. GLUT-4 protein is the major isoform in skeletal muscle responsible for insulin-stimulated glucose uptake. Although muscle GLUT-4 protein is unaltered in obesity and type 2 diabetes, levels of GLUT-4 decline with age, and are directly related to insulin sensitivity in normal, nondiabetic controls [40]. This suggests that these transporters may contribute to 
the insulin resistance observed with aging, possibly because of a decline in physical activity. Serum levels of insulin-like growth factor-1 (IGF-1) have been shown to be decreased in elderly people and such a reduction was correlated to insulin resistance in this population [41]. Finally, insulin is known to stimulate blood flow by an endothelium-dependent mechanism. Insulin-mediated blood flow is impaired with normal aging, and there is an even greater impairment in this parameter in elderly patients with diabetes [42, 43]. However, the role of the alteration in insulin-mediated vasodilatation in the insulin resistance that occurs with aging and diabetes remains uncertain.

\section{Impaired insulin secretion}

It has been long recognized that amyloid deposition is present in the pancreas of older diabetic patients and amylin may play a role in decreasing insulin secretion in elderly patients with type 2 diabetes [44]. Age-related insulin secretory dysfunction may have a role in the alterations in glucose metabolism with age and may contribute to the high rates of glucose intolerance in the older population [13]. One challenge in studying the time course of development of abnormal glucose tolerance in any population, and especially in the elderly population, is the sensitivity of tests to detect early abnormalities of $\beta$-cell function [45]. The earliest insulin secretory defects in the progression from normal to abnormal glucose tolerance may be subtle. Thus, sensitive measures of $\beta$-cell function are crucial, as well as the appropriate assessment of insulin secretion regarding possible concomitant diminished insulin sensitivity [46] (Table II).

\section{The effect of age on $\beta$-cell sensitivity to glucose}

Many studies have used insulin levels in response to an OGTT to assess insulin secretion. Although the OGTT is standardized, simple to perform, and widely used, the $\beta$-cell stimulus is complex (including not only glucose but gastrointestinal and neural factors) and variable over time. Thus, studies using the OGTT are difficult to interpret in light of the low sensitivity and specificity of insulin levels in response to oral glucose as a surrogate measure of pancreatic $\beta$-cell function. In addition, factors affecting insulin sensitivity, such as adiposity, may play a crucial role. Insulin levels in response to oral glucose load were found to decline significantly with age, after adjustments were made for body habitus (and thus indirectly for obesity-related insulin resistance) [47]. In addition, a delayed insulin response in the first hour after oral glucose load has been described in older people compared with young adults [48].

The frequently-sampled intravenous glucose tolerance test provides an assessment of both first- and secondphase insulin release as well as insulin sensitivity. Absolute defects in acute insulin response to intravenous glucose related to age alone have not been clearly demonstrated in early studies $[49,50]$, despite older subjects being glucose intolerant (but not in the diabetic range). In a more recent study [51], when subjects were classified by glucose tolerance status, older individuals with impaired glucose tolerance were insulin-resistant and tended to have lower acute insulin response to glucose and lower glucose effectiveness compared with older people with normal glucose tolerance.

The hyperglycaemic clamp is a valuable technique to assess $\beta$-cell function, because it allows to nicely discriminate between early and late insulin responses. Previous studies using this method have shown little or no decrease in insulin secretion with age [29, 52-54]. However, none of these studies took into account the effect of age-related insulin resistance on $\beta$-cell function (see below).

Finally, in a study using a stepped glucose infusion and C-peptide kinetics, no age difference was found in absolute insulin secretion rates [53]. However, this study suggested a decreased relative insulin response to stepped glucose infusion in old subjects when differences in glucose levels and insulin sensitivity between old and young subjects were considered.

\section{The effect of age on $\beta$-cell response to non-glucose stimuli}

$\beta$-cell function can be evaluated using a nonglucose stimulus such as arginine. In a study examining argininestimulated insulin response in young and old men, $\beta$-cell secretory capacity was $48 \%$ lower with arginine stimulus in the old subjects [50]. 
Table II: Contributors, markers and possible mechanisms of defects in insulin secretion in elderly people. Please note that some markers were not consistently found in all studies.

\section{Contributors}

Poor dietary habits (increased fat, decreased carbohydrate)

Concomitant drugs

\section{Markers}

Disturbed insulin pulsatility

Increased plasma proinsulin and proinsulin/insulin ratio

Decreased amylin secretion

Decreased post-glucose load early plasma insulin levels (OGTT)

Decreased (NS) early and late insulin response (hyperglycaemic clamp)

Decreased acute insulin response to intravenous glucose (IVGTT)

Decreased relative insulin response to stepped glucose infusion

Decreased insulin response to non glucose stimuli (arginine)

Decreased $\beta$-cell function relative to concomitant insulin resistance (various tests)

\section{Potential mechanisms}

Decreased age-related $\beta$-cell mass

Increased pancreatic islet amylin deposition

Decreased $\beta$-cell sensitivity to glucose

Decreased $\beta$-cell sensitivity to gut incretin hormones

\section{The effect of age on insulin processing}

An increased circulating proinsulin-to-insulin ratio in response to oral glucose challenge has been described in older adults [55]. However, these results were not confirmed in another study performed in old and young subjects matched for body mass index (BMI), showing similar proinsulinaemia in response to intravenous glucose and arginine [56]. Therefore, it is doubtful that a possible alteration in insulin processing inside the $\beta$ cell could represent a major predisposing factor to the development of glucose intolerance in the elderly population. Finally, an interesting observation reported that the release of the $\beta$-cell peptide amylin is reduced in older subjects, a finding in agreement with decreased $\beta$-cell function in elderly [57].

\section{The effect of age on insulin pulsatility}

Normal insulin secretion is pulsatile and orderly, with both rapid, low-amplitude pulses, which occur every 8-15 min, and ultradian pulses, which have a larger amplitude and occur every 60-140 min. In the fasting state, older subjects have been found to have more disorderly insulin release, with decreased amplitude and mass of rapid insulin pulses and reduced frequency of ultradian pulses compared with young subjects [58]. In response to a 10$\mathrm{h}$ sustained glucose infusion, old subjects displayed reduced frequency, amplitude, and regularity of ultradian pulses compared with young subjects matched for BMI [59]. We evaluated insulin response to a 53-h constant glucose infusion in weight-matched young and old subjects [60]. The elderly subjects had decreased pulse amplitude and decreased responsiveness of insulin secretion to oscillations in plasma glucose. Alterations in the ultradian oscillations of insulin secretion in aging were related to a partial breakdown in the negative feedback loop between insulin secretion and glucose, mainly due to decreased $\beta$-cell responsiveness in older people [60], The slowing of the rapid insulin oscillations has been shown to participate in the abnormalities of glucose and lipid metabolism in the elderly [61]. The analogy between the abnormalities seen in older healthy adults and those reported in patients with type 2 diabetes suggests that alterations in oscillations in insulin secretion could represent an early defect causing decreased glucose tolerance in aging.

\section{The effect of age on incretin $\beta$-cell potentiation}

The enteroinsular axis refers to the glucose-stimulated gut hormones, or incretin hormones, that potentiate insulin release. Age-related alteration in the incretin hormones, including glucose-dependent insulinotropic polypeptide (GIP) and glucagon-like peptide 1 (GLP-1), has been of interest as a possible contributing factor to the impaired insulin secretion and the glucose intolerance seen with advancing age. Basal and post-oral glucose load GIP and GLP-1 levels have been found to be unchanged or increased in healthy old people compared with 
young controls [62-64], Furthermore, exogenous infusion of GIP demonstrated that the potentiation of insulin response caused by GIP was greater in the young subjects than in the old during moderate hyperglycaemia [65]. These observations suggest that $\beta$-cell sensitivity to incretin hormones may be impaired in old people compared with younger controls. It has been hypothesized that this age-related impairment of insulin secretion to insulinotropic hormones, GIP and GLP-1, contributes to a reduction in glucose tolerance in elderly people [62].

\section{Interplay between insulin sensitivity and insulin secretion}

Type 2 diabetes, also the form commonly observed in elderly people, is characterized by a defect in both insulin action and insulin secretion $[8,66,67]$. Lean elderly patients with type 2 diabetes have a profound impairment in glucose-induced insulin release but only mild resistance to insulin-mediated glucose disposal, whereas obese elderly patients with type 2 diabetes have adequate circulating insulin levels but marked resistance to insulinmediated glucose disposal [25]. In a careful study assessing pancreatic islet function by C-peptide measurements and kinetics, no age differences were found in absolute insulin secretion between young and old non diabetic individuals [53]. However, this study suggested a decreased relative insulin response to stepped intravenous glucose infusion in old subjects when differences in glucose levels and insulin sensitivity between old and young subjects were considered.

There is a dynamic interaction between insulin secretion and insulin action: the hyperbola that describes the relationship between insulin sensitivity and insulin release implies that a feedback loop governs the interaction between the $\beta$-cell and the insulin-sensitive tissues [46]. Potential explanations for variable results when agingrelated defects in $\beta$-cell function are assessed include differences in age-related variables, not only obesity (abdominal adiposity) and physical activity, but also insulin resistance. The product of insulin sensitivity and the insulin response provides a true measure of $\beta$-cell function, rather than the insulin or C-peptide response examined in isolation. The product of insulin sensitivity and the acute insulin response to intravenous glucose, called the disposition index, is constant in individuals with normal glucose tolerance [46]. Older subjects, as other individuals at high risk to develop type 2 diabetes, have been shown to have $\beta$-cell dysfunction, manifest as a first-phase insulin response to intravenous glucose that is reduced relative to the degree of insulin sensitivity, thus leading to a decreased disposition index $[23,46,68]$. When young and old subjects are matched for variables affecting insulin sensitivity, reduced $\beta$-cell function with aging has been detected, with reduction by $46 \%$ of acute insulin response to intravenous glucose [68] and reduction by $56 \%$ of second-phase insulin secretion [69]. To assess $\beta$-cell compensation to the insulin resistance of aging, $\beta$-cell function was measured both as the acute ability of glucose to directly stimulate the pancreatic $\beta$-cells to secrete insulin (AIR glucose) and as the ability of glucose to potentiate the $\beta$-cell insulin response to arginine (AIRmax) in groups of young and older subjects [56]. $\beta$-cell function is reduced in older subjects when the degree of insulin sensitivity is taken into account (decreased SI x AIRglucose and SI x AIRmax). The product of SI and fasting insulin was also significantly lower in the older subjects than in the young, and the hyperbolic fit for the relation between SI and IRI was significantly different between the younger and older subjects. These data suggest that although aging does not affect the hyperbolic relationship between insulin sensitivity and fasting insulin, it appears to change the quantitative interaction, with lower $\beta$-cell compensation in older subjects.

\section{Conclusion}

The development of glucose intolerance has been well established to be a part of the human aging process. This change in glucose metabolism has been shown to be due to diminished sensitivity to insulin at its target tissues, especially skeletal muscle, and to inappropriately low pancreatic $\beta$-cell function. Thus, both insulin resistance and reduced compensation in $\beta$-cell function explain the higher risk of impaired glucose tolerance and type 2 diabetes in older individuals. Lifestyle modifications including body weight loss and regular physical activity provide health benefits and functional gains, and should be promoted to increase insulin sensitivity and prevent or improve glucose intolerance and type 2 diabetes mellitus in older adults.

\section{References}

1. Finucane P, Sinclair AJ (eds). Diabetes in old age. Chichester: John Wiley, 1995, 302 pages.

2. Scheen AJ. Non-insulin-dependent diabetes mellitus in the elderly. Bailliere's Clin Endocrinol Metab 1997;11:389-406.

3. Blicklé JF, Attali JR, Barrou Z, et al. Rapport des experts de l'ALFE-DIAM. Le diabète du sujet âgé. Diabetes Metab 1999;25:84-93. 
4. Meneilly GS, Tessier D. Diabetes in elderly adults. J Gerontol A Biol Sci Med Sci 2001;56:M5-M13.

5. Verny C, Neiss M, Rabier P, Lepeu-Moinon I. Diabète du sujet âgé. In: Grimaldi A, éd. Traité de Diabétologie. Paris: Flammarion Médecine-Sciences 2005;800-10.

6. Harris MI, Flegal KM, Cowie CC, et al. Prevalence of diabetes, impaired fasting glucose, and impaired glucose tolerance in US adults. Diabetes Care 1998;21:518-24.

7. Scheen AJ. Pathophysiology of type 2 diabetes. Acta Clin Belg 2003; 58:335-41.

8. DeFronzo RA. Pathogenesis of type 2 diabetes mellitus. Med Clin N Am 2004;88:787-835.

9. Paolisso G, Scheen A, Lefèbvre P. Glucose handling, diabetes and aging. Horm Res 1995;43:52-7.

10. Evans W, Farrell P. The aging pancreas: effects of aging on insulin secretion and action. In: Jefferson LS, Cherrington AD, eds. Handbook of Physiology. Section 7: The endocrine system. Vol 2: The endocrine pancreas and regulation of metabolism. Oxford: Oxford University Press 2001;969-98.

11. Ehahi D, Muller DC, Egan JM, Andres R, Veldhuist J, Meneilly GS. Glucose tolerance, glucose utilization and insulin secretion in ageing. Novartis Found Symp 2002;242:222-42 (discussion 242-6).

12. Ryan AS. Insulin resistance with aging: effects of diet and exercise. Sports Med 2000;30:327-46.

13. Chang AM, Halter JB. Aging and insulin secretion. Am J Physiol Endocrinol Metab 2003;284:E7-12.

14. Forbes A, Elliott T, Tildesley H, Finegood D, Meneilly GS. Alterations in non-insulin-mediated glucose uptake in the elderly patient with diabetes. Diabetes 1998;47:1915-9.

15. Scheen AJ, Lefèbvre PJ. Insulin action in man. Diabetes Metab 1996;22:105-10.

16. Scheen AJ. Le concept d'insulinosensibilité. Diabetes Metab 2001;27: 193-200.

17. Scheen AJ, Paquot N, Castillo MJ, Lefèbvre PJ. How to measure insulin action in vivo. Diab Metab Rev 1994;10:151-88.

18. Broughton DL, Taylor R. Deterioration of glucose tolerance with age: the role of insulin resistance. Age Ageing 1991;20:221-5.

19. Paolisso G, Tagliamonte MR, Rizzo MR, Giugliano D. Advancing age and insulin resistance: new facts about an ancient history. Eur J Clin Invest 1999;29:758-69.

20. Ferrannini E, Vichi S, Beck-Nielsen H, et al. Insulin action and age. Diabetes 1996;45:947-53.

21. Imbeault P, Prins JB, Stolic M, et al. Aging per se does not influence glucose homeostasis. In vivo and in vitro evidence. Diabetes Care $2003 ; 26: 480-4$.

22. Chen M, Bergman RN, Porte D Jr. Insulin resistance and $\beta$-cell dysfunction in aging: the importance of dietary carbohydrate. J Clin Endocrinol Metab 1988;67:951-7.

23. Kahn SE, Larson VG, Beard JC, et al. Effect of exercise on insulin action, glucose tolerance, and insulin secretion in aging. Am J Physiol 1990;258:E937-43.

24. Lefèbvre P, Paquot N, Scheen A. Le rôle du foie dans l'homéostasie glucidique : une relecture des travaux de Claude Bernard. Journ Annu Diabetol Hôtel-Dieu 1996;1-9.

25. Meneilly G, Minaker K, Elahi D, Rowe J. Insulin action in aging man: evidence for tissue-specific differences at low physiologic insulin levels. J Gerontol 1987;42:196-201.

26. Natali A, Toschi E, Carnastra S, Gastaldelli A, Groop L, Ferrannini E. Determinants of postabsorptive endogenous glucose output in non-diabetic subjects. European Group for the Study of Insulin Resistance (EGIR). Diabetologia 2000;43:1266-72.

27. Meneilly GS, Elliott T, Tessier D, et al. NIDDM in the elderly. Diabetes Care 1996;19:1320-5.

28. Rowe J, Minaker K, Pallota J, Flier J. Characterization of the insulin resistance of aging. J Clin Invest 1983;71:1581-7.

29. DeFronzo RA. Glucose intolerance and aging: evidence for tissue insensitivity to insulin. Diabetes 1979;28:1095-101.

30. Fink RI, Kolterman OG, Griffin J, Olefsky JM. Mechanisms of insulin resistance in aging. J Clin Invest 1983;71:1523-35. 
31. Cefalu WT, Wang ZQ, Werbel S, et al. Contribution of visceral fat mass to the insulin resistance of aging. Metabolism 1995;44:954-

32. Coon PJ, Rogus EM, Drinkwater D, et al. Role of body fat distribution in the decline of insulin sensitivity and glucose tolerance with age. J Clin Endocrinol Metab 1992;75:1125-32.

33. Kohrt WM, Kirwan JP, Staten MA, et al. Insulin resistance in aging is related to abdominal obesity. Diabetes 1993;42:273-81

34. Scheen AJ. Current management strategies for coexisting diabetes mellitus and obesity. Drugs 2003;63:1165-84.

35. Goodpaster BH, Thaete FL, Simoneau JA, et al. Subcutaneous abdominal fat and tight muscle composition predict insulin sensitivity independently of visceral fat. Diabetes 1997;46:1579-85.

36. Rice CL, Cunningham DA, Paterson DH, et al. Arm and leg composition determined by computed tomography in young and elderly men. Clin Physiol 1989;9:207-20.

37. Winder WW, Hardie DG. AMP-activated protein kinase, a metabolic master switch: possible roles in type 2 diabetes. Am J Physiol 1999;277: E1-10.

38. Kirwan JP, Kohrt WM, Wojta DM, et al. Endurance exercise reduces glucose stimulated insulin levels in 60-70 year old men and women. J Gerontol 1993;48:M84-90.

39. Tonino RP. Effect of physical training on the insulin resistance of aging. Am J Phsyiol 1989;256:E352-6.

40. Houmard JA, Weidner MD, Dolan PL, et al. Skeletal muscle GLUT4 protein concentration and aging in humans. Diabetes $1995 ; 44: 555-60$

41. Paolisso G, Ammendola S, Del Buono A, et al. Serum levels of insulin-like growth factor-1 (IGF-1) and IGF-binding protein-3 in healthy centenarians: relationship with plasma leptin and lipid concentrations, insulin action, and cognitive function. J Clin Endocrinol Metab 1997;82:2204-9

42. Meneilly GS, Elliott T, Bryer-Ash M, Floras JS. Insulin-mediated increase in blood flow is impaired in the elderly. J Clin Endocrinol Metab 1995;80:1899-903.

43. Meneilly GS, Elliott T Metabolic alterations in middle-aged and elderly obese patients with type 2 diabetes. Diabetes Care $1999 ; 22: 112-8$

44. Castillo MJ, Scheen AJ, Lefèbvre PJ. Amylin/Islet amyloid polypeptide: biochemistry, physiology, patho-physiology. Diabetes Metab 1995;21:3-25

45. Scheen AJ. Pathophysiology of insulin secretion. Ann Endocrinol (Paris) 2004;65:29-36.

46. Kahn SE. The relative contributions of insulin resistance and beta-cell dysfunction to the pathophysiology of type 2 diabetes. Diabetologia 2003;46:3-19

47. Muller DC, Elahi D, Tobin JD, Andres R. Insulin response during the oral glucose tolerance test: the role of age, sex, body fat and the pattern of fat distribution. Aging Clin Exp Res 1996;8:13-21.

48. Chen M, Halter JB, Porte D Jr. Pathogenesis of age-related glucose intolerance of the elderly. J Am Geriatr Soc 1987;35:417-24.

49. Palmer JP, Ensinck JW. Acute-phase insulin secretion and glucose tolerance in young and aged normal men and diabetic patients. J Clin Endocrinol Metab 1975;41:498-503.

50. Chen M, Bergman RN, Pacini G, et al. Pathogenesis of age related glucose intolerance in man: insulin resistance and decreased insulin secretion. J Clin Endocrinol Metab 1985;60:13-20.

51. Garcia GV, Freeman RV, Supiano MA, Smith MJ, Galecki AT, Halter JB. Glucose metabolism in older adults: a study including subjects more than 80 years of age. J Am Geriatr Soc 1997;45:813-7.

52. Elahi D, Muller DC, McAloon-Dyke M, Tobin JD, Andres R. The effect of age on insulin response and glucose utilization during four hyperglycaemic plateaus. Exp Gerontol 1993;28:393-409.

53. Gumbiner B, Polonsky KS, Beltz WF, Wallace P, Brechtel G, Fink RI. Effects of aging on insulin secretion. Diabetes 1989;38:1549-

56

54. Bourey RE, Kohrt WM, Kirwan JP, Staten MA, King DS, Holloszy JO. Relationship between glucose tolerance and glucosestimulated insulin response in 65-year-olds. J Gerontol 1993;43:M122-7. 
55. Shimuzu M, Kawazu S, Tomono S, et al. Age-related alteration of pancreatic beta-cell function: increased proinsulin and proinsulinto-insulin molar ratio in elderly, but not in obese, subjects without glucose intolerance. Diabetes Care 1996;19:8-11.

56. Roder ME, Schwartz RS, Prigeon RL, Kahn SE. Reduced pancreatic $\beta$-cell compensation to the insulin resistance of aging: impact on proinsulin and insulin levels. J Clin Endocrinol Metab 2000;85:2275-80.

57. Dechenes CJ, Verchere CB, Andrikopoulos S, Kahn SE. Human aging is associated with parallel reductions in insulin and amylin release. Am J Physiol 1998;275:E785-91.

58. Meneilly GS, Ryan AS, Velhuis JD, Elahi D. Increased disorderliness of basal insulin release, attenuated insulin secretory burst mass, and reduced ultradian rhythmicity of insulin secretion in older individuals. J Clin Endocrinol Metab 1997;82:4088-93.

59. Meneilly GS, Veldhuis JD, Elahi D. Disruption of the pulsatile and entropic modes of insulin release during an unvarying glucose stimulus in elderly individuals. J Clin Endocrinol Metab 1999;84:1938-43.

60. Scheen AJ, Sturis J, Polonsky KS, et al. Alterations in the ultradian oscillations of insulin secretion and plasma glucose in aging. Diabeto-logia 1996;39:564-72.

61. Paolisso G, Salvatore T, Sgambato S, et al. Metabolic effects of pulsatile insulin infusion in the elderly. Acta Endocrinol 1990;123:19-23.

62. Ranganath L, Sedgwick I, Morgan L, Wright J, Marks V. The ageing entero-insular axis. Diabetologia 1998;41:1309-13.

63. Meneilly DS, Demuth HU, Mcintosh CHS, Pederson RA. Effect of ageing and diabetes on glucose-dependent insulinotropic polypeptide and dipeptidyl peptidase IV responses to oral glucose. Diabet Med 2000;17:346-50.

64. Korosi J, Mcintosh CHS, Pedersen RA, et al. Effect of aging and diabetes on the enteroinsular axis. J Gerontol Med Sci 2001;56A:M575-9

65. Meneilly GS, Ryan AS, Minaker KL, Elahi D. The effect of age and glycaemic level on the response of the $\beta$-cell to glucosedependent insulinotropic polypeptide and peripheral tissue sensitivity to endoge-nously released insulin. J Clin Endocrinol Metab $1998 ; 83: 2925-32$

66. Scheen AJ, Lefèbvre PJ. Insulin resistance versus insulin deficiency: which one comes first? The old question revisited. In: Di Mario U, Leonetti F, Pugliese G, Sbraccia P, Signore A, eds. Diabetes in the New Millennium. New York: Wiley \& Sons 2000;101-13.

67. Ferrannini E. Insulin resistance versus insulin deficiency in non-insulin-dependent diabetes mellitus: problems and prospects. Endocr Rev 1998;19:477-90.

68. Kahn SE, Larson VG, Schwartz RS, et al. Exercise training delineates the importance of $\beta$-cell dysfunction to the glucose intolerance of human aging. J Clin Endocrinol Metab 1992;74:1336-42.

69. Ahren B, Pacini G. Age-related reduction in glucose elimination is accompanied by reduced glucose effectiveness and increased hepatic insulin extraction in man. J Clin Endocrinol Metab 1998; 83:3350-6. 